\title{
PENGARUH KEPEMILIKAN MANAJERIAL, KEPEMILIKAN INSTITUSIONAL, KOMISARIS INDEPENDEN, KOMITE AUDIT, SERTA KULITAS AUDIT PADA NILAI PERUSAHAAN
}

\author{
Muhammad Nuryono ${ }^{1)}$, Anita Wijayanti ${ }^{2)}$, Yuli Chomsatu Samrotun ${ }^{3)}$ \\ ${ }^{1,2,3)}$ Program Studi Akuntansi Fakultas Ekonomi Universitas Islam Batik Surakarta \\ E-mail: ${ }^{1}$ mnuryono26@gmail.com
}

\begin{abstract}
Abstrak : Penelitian dilakukan untuk menguji dan menganalisis pengaruh kepemilikan manajerial (MOWN), kepemilikan institusional (INST), komisaris independen (KI), komite audit (KA) dan kualitas audit (KuA) terhadap nilai emiten pertambangan yang listing di Bursa Efek Indonesia (BEI) selama tahun 2015-2017. Sampel penelitian terdiri atas 63 emiten dan dipilih secara purposive sampling (dengan kriteria tertentu). Analisis data menggunakan analisis regresi linier berganda. Hasil penelitian menunjukkan secara simultan, kepemilikan manajerial (MOWN), kepemilikan institusional (INST), komisaris independen (KI), komite audit (KA) dan kualitas audit $(K u A)$ berpengaruh terhadap nilai perusahaan $(P B V)$. Secara parsial, kepemilikan institusional yang berpengaruh positif signifikan terhadap nilai perusahaan, sedangkan variabel bebas lainnya (kepemilikan manajerial, komisaris independen, komite audit dan kualitas audit) berpengaruh positif tetapi tidak signifikan terhadap nilai perusahaan.
\end{abstract}

Kata Kunci : Kepemilikan Manajerial (MOWN), Kepemilikan Institusional (INST), Komisaris Independen, Komite audit, Kualiats Audit, Firm Size, PBV

\section{PENDAHULUAN}

Pasar modal yang berubah secara berkesinambungan membuat intensitas persaingan emiten di bursa saham semakin kompetitif. Persaingan tersebut mendorong manajer untuk lebih proaktif dan berkompeten dalam meningkatkan kinerja yang berkaitan dengan pencapaian tujuan perusahaan. Tujuan perusahaan sebagai entitas ekonomi pada dasarnya tidak hanya terkosentrasi untuk kemaksimalan laba dengan pengalokasian sumber daya yang ada, tetapi juga mendongkrak aktivitas ekonomi untuk meningkatkan nilai perusahaan, sehingga berimplikasi pada meningkatnya kemakmuran investor. (Timbuleng, dkk 2015).

Penelitian Nurlela \& Islahuddin (2008) dan Suprapti \& Herawati (2013) membuktikan secara empiris bahwa nilai perusahaan dapat dimaksimalkan manakala para pemegang saham mendelegasikan pengelolaan perusahaan kepada orang-orang yang mahir dalam bidangnya, seperti manajer maupun komisaris. Namun, dalam proses peningkatan nilai perusahaan terkadang mengalami berbagai kendala, salah satu diantaranya adalah konflik agensi yang disebabkan oleh benturan kepentingan dan ketimpangan informasi antara pihak manajemen dengan investor. Alternatif solusi dalam pengendalian konflik tersebut diantaranya yakni peningkatan kepemilikan manajerial (Jesen \& Meckling, 1976), peningkatan kepemilikan institusional (Haruman, 2008) dan peningkatan pendapatan melalui hutang.

Penelitian Sholekah \& Venusita (2014), Marius \& Masri (2017) dan Widyaningsih (2018) menyimpulkan bahwa proporsi kepemilikan manajerial berpotensi meningkatkan nilai perusahaan. kepemilikan saham yang tinggi oleh manajer secara otomatis akan meningkatkan kinerja manajer, karena setiap kebijakan maupun tindakan yang diambil dalam mengelola perusahaan akan berimbas kepada jumlah ekuitas yang ditanamkan dalam perusahaan tersebut. Relevansi berbeda ditunjukkan pada beberapa penelitian yang menyimpulkan tidak berpengaruhnya kepemilikan manajerial dan kepemilikan institusional terhadap nilai perusahaan, seperti penelitian Dewi \& Nugrahanti (2014), Dewi \& Sanica (2017) dan Yuslirizal (2017). 
Inkonsisten penelitian juga terjadi pada pengaruh kepemilikan institusional terhadap nilai perusahaan, seperti penelitian Dewi \& Nugrahanti (2014), Sholekah \& Venusita (2014), Dewi \& Sanica (2017) dan Yuslirizal (2017) yang menyimpulkan bahwa kepemilikan institusional tidak berpengaruh terhadap nilai perusahaan. Namun demikian Tarjo (2008), Gwenda \& Juniarti (2013) dan Rustan dkk (2014), menyimpulkan bahwa kepemilikan institusional secara signifikan berpengaruh terhadap nilai perusahaan. kepemilikan yang dominan oleh pihak institusi merupakan mekanisme kontrol eksernal terhadap tindakan oportunis manajer yang dapat menghambat peningkatan nilai perusahaan.

Strukur kepemilikan yang relatif mendominasi sebagai bentuk pengendalian konflik agensi dapat memicu resiko ekspropriasi terhadap pemegang saham minoritas. Ekspropriasi merupakan proses penggunaan kontrol untuk memaksimalkan kesejahteraan sendiri dengan distribusi kekayaan dari pihak lain (Claessens, et al, 2000). Oleh karenanya diperlukan penerapan tata kelola perusahaan yang baik (Good Corporate Governance) dari pihak independen agar agensi konflik maupun ekspropriasi dapat dikendalikan.

Good Corporate Governance (GCG) merupakan serangkaian mekanisme atau proses terintegrasi yang digunakan oleh semua jajaran manajemen dan karyawan perusahaan dalam menjalankan operasional perusahaan sehingga mencapai keseimbangan antara kekuatan serta kewenangan perusahaan dalam memberikan pertanggungjawaban kepada pihak-pihak yang berkepentingan, shareholder pada khususnya dan stakeholder pada umumnya. GCG erat kaitanya dengan nilai perusahaan, hal ini dikarenakan implementasi prinsip-prinsip GCG bertujuan untuk meningkatkan nilai perusahaan melalui kinerja perusahaan yang baik. Pada penelitian ini mekanisme GCG diproksikan melalui komisaris independen dan komite audit.

Peran komisaris independen sebagai sentral mekanisme kontrol dalam perusahaan adalah berkewajiban membantu merencanakan strategi jangka panjang perusahaan, kemudian melakukan review atas implementasi strategi tersebut secara berkala (Purwantini, 2011). Hasil penelitian Purwantini (2011), Firdausya dkk (2013) dan Widyaningsih (2018) menyimpulkan bahwa keberadaan komisaris independen tidak berpengaruh terhadap nilai perusahaan. Namun demikian Dewi \& Nugrahanti (2014) menyimpulkan bahwa komisaris independen berpengaruh terhadap nilai perusahaan.

Komite Audit sebagai pihak independen hendaknya kerap menjalin komunikasi secara efektif dengan komisaris, direksi, maupun auditor internal dan eksternal melalui rapat internal (Effendy, 2016). Menurut Raharja (2014), Marius \& Masri (2017), Amrizal A dkk (2017) dan Syafitri dkk (2018) komite audit berpengaruh negatif dan signifikan terhadap nilai perusahaan, sedangkan menurut Widyasari, dkk (2015) dan Widyaningsih (2018) menyimpulkan bahwa komite audit bepengaruh positif terhadap nilai perusahaan.

Perusahaan berskala besar atau yang memiliki asset besar berpotensi terjadi agensi konflik maupun ekpropriasi. Oleh karena itu perusahaan menerapkan tatakelola yang baik sebagai landasan hukumnya dan menggunakan auditor eksternal yang berstandarisasi (KAP Big Four) agar informasi yang dikeluarkan relevan. Hal ini sebagai bentuk menjaga reputasi perusahaan atas kepercayaan investor.

\section{KAJIAN TEORI}

\section{Teori Keagenan (Agency Theory)}

Agency theori merupakan landasan teoritis dalam pengembangan penelitian ini. Menurut (Jesen \& Meckling, 1976), teori agensi adalah suatu teori yang menjelaskan hubungan kerjasama antara investor (principal) dengan manajer yang mengelola perusahaan (agent). Prinsipal selaku fasilitator operasional dan penyandang dana mendelegasikan wewenang kepada agen untuk mengelola kekayaan investor sebagaimana mestinya, sehingga investor mempunyai harapan bahwa dengan mendelegasikan wewenang 
pengelolan tersebut mereka akan memperoleh keuntungan dengan bertambahnya kekayaan maupun kemakmuran investor.

\section{Teori signal}

Teori sinyal digunakan dalam penelitian ini karena informasi yang dikeluarkan oleh manajemen atau perusahaan melalui kualitas audit berstandarisasi sebenarnya merupakan sinyal secara implisit kepada investor terkait bagaimana manajemen memandang prospek perusahaan. Teori sinyal diharapkan dapat mengurangi ketimpangan informasi antara manajer dengan para investor. Dengan informasi yang transparan dan akuntabel dalam bentuk laporan tahunan dari pihak perusahaan dapat meningkatkan reputasi perusahaan dan kepercayaan investor sehingga mau menanamkan modalnya pada perusahaan tersebut.

\section{Kepemilikan Manajerial}

Kepemilikan manajerial menunjukkan jumlah persentase saham pihak manajemen yang aktif terlibat dalam proses pengelolaan perusahaan (direksi dan komisaris) atau seluruh modal dalam perusahaan (Effendy, 2016). Menurut Jesen \& Meckling (1976) salah satu cara untuk mengendalikan konflik keagenan dalam perusahaan adalah dengan mensejajarkan tujuan manajemen dengan pemegang saham perusahaan tersebut, yaitu dengan cara kepemilikan manjerial (insider ownership). Sehingga selain menjadi pengelola perusahaan, manajemen merangkap peran sebagai pemegang saham perusahaan tersebut. Hal tersebut akan membuat manajer meningkatkan kinerjanya dan berhati-hati dalam pengambilan keputusan, karena manajer akan memperoleh manfaat langsung dari berbagai keputusan yang diambilnya, serta menangung konsekuensi dari pengambilam keputusan yang salah.

\section{Kepemilikan Institusional}

Kepemilikan institusional merupakan mekanisme eksternal dalam memonitor manajemen untuk mengelola perusahaan. Kepemilikan institusional adalah kepemilikan saham perusahaan yang dimiliki oleh institusi atau lembaga seperti perusahaan asuransi, bank, perusahaan investasi, dana pensiun dan kepemilikaan lain (Tarjo, 2008).

\section{Komisaris Independen}

Komisaris independen adalah komisaris yang berasal dari pihak luar yang diangkat berdasarkan keputusan Rapat Umum Pemegang Saham (RUPS) dari pihak yang tidak terafiliasi dengan pemegang saham utama, anggota direksi perseroan dan anggota dewan komisaris lainya. Sehingga jalanya pengurusan dan kebijakan perusahaaan akan bersifat transparan, akuntabel, adil dan bertanggungjawab baik terhadap pemegang saham maupun kepada pemangku kepentingan lainya. Dewan komisaris independen memegang peranan yang sangat penting dalam perusahaan, terutama dalam pelaksanaan mekanisme penerapan GCG, melalui tugasnya untuk menjamin pelaksanaan strategi perusahaan, mengawasi manajemen dalam mengelola perusahaan dan mewajibkan terlaksananya akuntabilitas.

\section{Komite Audit}

Komite audit merupakan suatu komite yang bekerja secara professional dan independen yang dibentuk oleh dewan komisaris dengan demikian tugasnya adalah membantu dan memperkuat fungsi dewan komisaris atau dewan pengawas dalam menjalankan fungsi pengawasan atas proses pelaporan keuangan, manajemen resiko, pelaksanaan audit, dan implementasi dari corporate governance di perusahaan-perusahaan. (Ikatan Komite Audit Indonesia, dalam (Effendy, 2016). Menurut Bapepam melalui SE03/PM/2000 dan Keputusan Direksi Bursa Efek Jakarta (BEJ) No. Kep-315/BEJ/06/2000 komite audit sekurang-kurangnya terdiri dari tiga orang anggota, salah satu diantaranya merupakan 
komisaris independen yang sekaligus merangkap sebagai ketua komite audit, sedangkan anggota lainnya merupakan pihak ekstern yang independen dimana sekurang - kurangnya satu diantaranya memiliki kemampuan di bidang akuntansi dan keuangan.

\section{Kualitas Audit}

Audit merupakan suatu poses untuk mengurangi ketimpangan informasi diantara manajemen dan para pemegang saham dengan mengunakan pihak luar untuk memberikan pengesahan terhadap laporan keuangan. Laporan keuangan perusahaan yang telah diaudit lebih memberikan fakta yang relevan bagi para pengguna laporan keuangan dalam mengambil keputusan. Kualitas audit diartikan sebagai bagus tidaknnya suatu pemeriksaan yang telah dilakukan oleh auditor. Berdasarkan Standar Profesional Akuntan Publik (SPAP) Audit yang dilaksanakan auditor dikatakan berkualitas, jika memenuhi kriteria atau standar pengauditan. Kategori KAP Big Four di indonesia yaitu :

1) KAP Price Waterhouse Coopers, yang bekerja sama dengan KAAP Drs. Hadi Susanto, KAP Tanudiredja, Wibisana dan Rekan, KAP Haryanto Sahari.

2) KAP KPMG ( Klynveld Peat Marwick Goerdeler ) yang bekerja sama dengan KAP Sidarharta dan Wijaya.

3) KAP Ernest \& Young, yang bekerja sama dengan KAP Drs. Sarwoko dan Sanjoyo, Prasetyo Purwantono.

4) KAP Deloitte Touche Thomatsu, yang bekerja sama dengan KAP Drs. Hans Tuanakota \& Osman Bing Satrio.

\section{Ukuran Perusahaan (Firm Size)}

Ukuran perusahaan merupakan besarnya perusahaan yang diukur dengan logaritma natural total asset (Asas, 2016). Ukuran perusahaan dapat diartikan sebagai suatu skala pengklasifikasian besar kecilnya suatu perusahaan berdasarkan jumlah ekuitas yang dimiliki atau organisasi yang didirikan oleh seseorang atau lebih untuk mencapai tujuannya. Perusahaan besar yang memiliki biaya keagenan yang lebih besar akan mengungkapkan informasi yang lebih luas untuk mengurangi agency cost.

\section{Nilai Perusahaan}

Nilai perusahaan adalah kondisi tertentu atas prestasi perusahaan sebagai gambaran dari kepercayaan masyarakat terhadap perusahaan tersebut. Nilai perusahaan dapat diukur dengan nilai pasar saham yang notabene merupakan refleksi dari penilaian oleh publik terhadap kinerja perusahaan secara riil.

Pada penelitian ini nilai perusahaan diproksikan dengan Price to Book Value (PBV). Rasio Price to Book Value (PBV) menunjukkan apakah harga saham (harga pasarnya) yang diperdagangkan di atas atau di bawah nilai bukunya. Price to Book Value (PBV) yang tinggi akan membuat meningkatkan kepercayaan pasar atas prospek perusahaan ke depan.

\section{KERANGKA KONSEPTUAL PENELITIAN}

Dari uraian maka dibuat suatu kerangka pemikiran teoritis yang menggambarkan hubungan antar variabel sebagai berikut : 


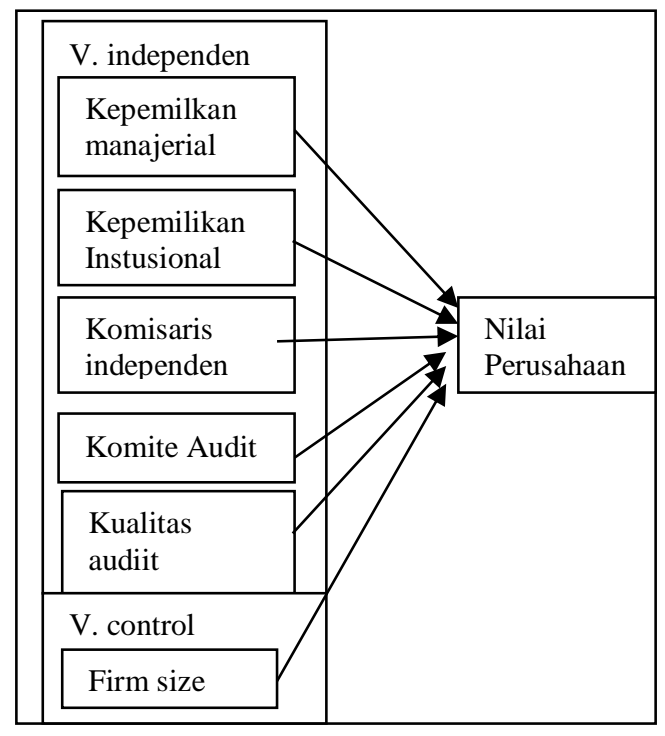

\section{HIPOTESIS PENELITIAN}

Hasil penelitian tentang pengaruh kepemilikan manajerial terhadap nilai perusahaan dikemukakan oleh Widyaningsih (2018) dan Syafitri, dkk (2018), Proporsi kepemilikan manajerial akan mengurangi agensi cost dan mensejajarkan kepentingan manajemen dengan pemegang saham, sehingga manajer akan memperoleh manfaat langsung dari berbagai keputusan yang diambil, serta menangung konsekuensi dari pengambilam keputusan yang salah.

H1:Kepemilikan manajerial, berpengaruh terhadap nilai perusahaan.

Semakin besar kepemilikan institusional maka semakin kuat tingkat pengendalian yang dilakukan pihak eksternal terhadap perusahaan sehingga dapat mengurangi agensi cost pada perusahaan dan nilai perusahaan semakin meningkat. Hal ini sesuai dengan penelitian Rustan dkk (2014) dan Amrizal \& Rohmah (2017) yang menyimpulkan bahwa kepemilikan institusional berpengaruh positif signifikan terhadap nilai perusahaan.

$\mathrm{H} 2$ :Kepemilikan institusional berpengaruh terhadap nilai perusahaan.

Komisaris idependen memegang peranan yang sangat penting dalam perusahaan, terutama dalam pelaksanaan mekanisme penerapan GCG, melalui tugasnya untuk menjamin pelaksanaan strategi perusahaan, mengawasi manajemen dalam mengelola perusahaan, serta mewajibkan terlaksananya akuntabilitas. Peranan komisaris independen dinilai dapat meningkatkan nilai perusahaan seperti halnya pada penelitian Dewi \& Nugrahanti (2014) dan Raharja (2014).

H3:Komisaris independen berpengaruh terhadap nilai perusahaan.

Baik dewan komisaris independen maupun komite audit mempunyai pengaruh signifikan terhadap integritas laporan keuangan. Keberadaan komite audit diharapkan dapat memberikan nilai tambah terhadap penerapan mekanisme GCG yang pada akhirnya dapat mengurangi terjadinya praktik manipulasi dalam informasi yang disajikan. Hal ini selaras dengan penelitian Widyasari, dkk (2015) dan Syafitri, dkk (2018) yang membuktikan bahwa komite audit mempengarhi nilai peusahaan.

H4:Komite audit berpengaruh terhadap nilai perusahaan. 
Kualitas Audit dapat diartikan sebagai bagus tidaknnya suatu pemeriksaan yang telah dilakukan oleh auditor. Berdasarkan Standar Profesional Akuntan Publik (SPAP) Audit yang dilaksanakan auditor dikatakan berkualitas, jika memenuhi ketentuan atau standar pengauditan. Menurut Widyasari, dkk (2015) dan Amrizal \& Rohmah (2017). Kualitas Audit tidak berpengaruh terhadap nilai perusahaan

H5: Kualitas Audit tidak berpengaruh terhadap nilai perusahaan.

Hasil penelitian tentang pengaruh Firm size terhadap nilai perusahaan sebagai variabel kontrol Firm size menunjukkan besar kecinlya perusahaan yang dinyatakan dengan total asset. Perusahaan akan mudah memperoleh sumber pendanaan, jika didukung informasi positif dari perusahaan. dengan modal yang besar maka perusahaan mudah melakukan ekspansi usaha sehingga perusahaan semakin berkembang. Hal ini sesuai dengan penelitian Raharja (2014) dan Widyaningsih (2018) bahwa Firm size berpengaruh terhadap nilai perusahaan. Firm size dalam penelitan ini dijadikan variabel kontrol untuk mengetahui apakah variabel firm size ini perlu dinetralisir, dikeluarkan, atau dipertahankan tetap.

H6 : Firm size berpengaruh terhadap nilai perusahaan dan mampu mengendalikan pengaruh variabel kepemilikan mnajerial, kepemilikan institusional, komisaris independen, komite audit dan kualitas audit terhadap nilai perusahaan.

\section{METODE PENELITIAN}

\section{Jenis Penelitian}

Jenis penelitian ini adalah penelitian kuantitatif dengan jenis penelitian asosiatif kausal, yaitu penelitian yang bertujuan untuk mengetahui pengaruh ataupun juga hubungan antara dua variabel dengan menekankan pada pengujian teori-teori melalui pengukuran variabel-variabel penelitian dengan angka (Sugiyono, 2015).

\section{Variabel Penelitian dan Pengukuranya}

1. Variabel Dependen ( Variabel Terikat)

Variabel dependen adalah variabel yang dipengaruhi oleh variabel lain. Dalam penelitian ini yang digunakan sebagai variabel dependen adalah nilai perusahaan yang diproksikan dengan Price to Book Value (PBV). PBV adalah rasio harga saham terhadap nilai buku perlembar saham. Standar pengukuranya:

PBV : $\underline{\text { Harga saham perlembar }} \times 100 \%$

Nilai buku perlembar saham

2. Variabel Independen (Variabel Bebas)

Variabel Independen adalah variabel yang mempengaruhi variabel dependen. Variabel Independen di dalam penelitian ini meliputi:

a. Kepemilikan manajerial

Kepemilikan Manajerial diproksikan dengan MOWN (Sholekah \& Venusita, 2014), yaitu prosentase jumlah saham yang dimiliki manajemen dibandingkan jumlah saham yang beredar. Standar pengukuranya:

MOWN : Jumlah saham manajemen x100\% Jumlah saham beredar 
b. Kepemilikan Institusional (Mutual Fund)

Kepemilikan Institusional diproksikan dengan INST (Sholekah \& Venusita, 2014), yaitu prosentase jumlah saham yang dimiliki institusi dibandingkan jumlah saham yang beredar. Standar pengukuranya:

$$
\text { INST }=\frac{\text { Jumlah saham institusi }}{\text { Jumlah saham beredar }} \times 100 \%
$$

c. Komisaris Independen

Komisaris Independen diukur dengan menggunakan prosentase jumlah anggota dewan komisaris dari luar perusahaan dibandingkan dengan seluruh anggota dewan komisaris perusahaan (Novalia, 2016). Standar pengukuranya:

$\mathrm{KI}=\frac{\mathrm{Jml} \text { dewan komisaris dari luar }}{\text { Seluruh dewankomisaris perusahaan }} \mathrm{x} 100 \%$

d. Komite Audit

Komite Audit diukur dengan menggunakan prosentase jumlah angota komite dari luar perusahaan dibandingkan dengan seluruh anggota komite audit (Novalia, 2016). Standar pengukuranya:

$\mathrm{KA}=$ Jumlah anggota komite luar $\mathrm{x} 100 \%$

Seluruh anggota komite audit

e. Kualias Audit

Kualitas Audit diukur dengan mengklasifikasikan atas audit yang dilakukan oleh KAP Big Four dan KAP Non-Big Four, Jika perusahaan diaudit oleh KAP Big Four maka diberi nilai 1 dan jika tidak diberi nilai 0 , Standar pengukuran:

$1=$ KAP Big Four

$0=$ KAP Non-Big Four

3. Variabel Kontrol

Variabel kontrol digunakan untuk menontrol hubungan antara variabel bebas dengan variabel terikat, karena variabel kontrol diduga ikut berpengaruh terhadap variabel bebas. Variabel kontrol dalam penelitian ini diproksikan dengan Firm Size. Firm Size digunakan untuk mengukur besarnya perusahaan berdasarkan total asset (Asas, 2016). Total aset diperoleh dari laporan posisi keuangan akhir periode pada laporan tahunan perusahaan.

Size $=$ Ln natural (total aset)

\section{HASIL ANALISIS DAN PEMBAHASAN}

\section{Uji Asumsi Klasik}

\section{a. Uji Normalitas}

Uji normalitas bertujuan untuk menguji apakah dalam model regresi, variabel pengganggu atau residual memiliki distribusi. Sebaran data berada pada nilai sig $>0,05$, sehiingga dapat didimpulkan bahwa data berdistribusi nnormal. 
Tabel 1. Hasil Uji Kolmogorov Smirnov

\begin{tabular}{ccc}
\hline $\begin{array}{c}\text { Indikator uji } \\
\text { normalitas }\end{array}$ & Value & Value asymp. Sig \\
\hline Asymp. Sig. (2- & 0,20 & $>0,05$ \\
\hline
\end{tabular}

\section{b. Uji Multikolinearitas}

Uji multikolinieritas bertujuan untuk menguji apakah model regresi ditemukan adanya korelasi antar variabel bebas (independen).

Tabel 2. Hasil Uji Multikolinieritas

\begin{tabular}{ccc}
\hline Variabel Indepedent & Tolerance & VIF \\
\hline $\begin{array}{c}\text { Kepemilikan } \\
\text { Manajerial }\end{array}$ & 0,903 & 1,107 \\
Kepemilikan & 0,970 & 1,031 \\
Institusional & & \\
Komisaris & 0,953 & 1,049 \\
Independen & 0,979 & 1,021 \\
Komite Audit & 0,892 & 1,121 \\
Kualitas Audit & & \\
\hline
\end{tabular}

Berdasarkan hasil uji multikolinearitas semua variabel diatas mempunyai nilai VIF $<10$ dan nilai tolerance $>0.10$, sehingga bebas multikolinieritas.

\section{c. Uji Autokorelasi}

Uji autokorelasi bertujuan untuk menguji ada tidaknya korelasi antara kesalahan pengganggu pada periode $t$ dalam model regresi linier.

Table 3. Hasil Uji autokorelasi

Pengujian autokorelasi dapat dilakukan menggunakan run test, dengan melihat nilai signifikansi > 0,05 maka model regresi tidak terdapat gejala autokorelasi.

\section{Uji Hipotesis}

\section{a. Uji Regresi Linier Berganda}

Uji analisis regresi bertujuan untuk menunjukkan arah hubungan antara variabel dependen dengan variabel independen. Pada penelitian ini digunakan analisis regresi berganda dengan persamaan penelitian sebagai berikut :

$\mathrm{Y}=\mathrm{a}+\beta 1 \mathrm{X}_{1}+\beta 2 \mathrm{X}_{2}+\beta 3 \mathrm{X}_{3}+\beta \mathrm{X}_{4}+\beta \mathrm{X}_{5}+\mathrm{z}+\mathrm{e}$

Keterangan :

$\mathrm{Y}=$ Nilai Perusahaan

$\mathrm{a}=$ Konstanta

$\beta=$ Koefisien Regresi

$\mathrm{X} 1=$ Kepemilikan Manajerial

$\mathrm{X} 2=$ Kepemilikan Institusional 


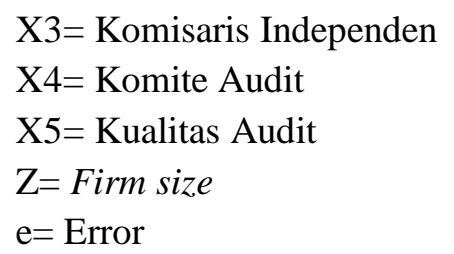

Tabel 4. Uji regresi linier

\begin{tabular}{lrr}
\hline \multirow{2}{*}{ Model } & \multicolumn{2}{c}{$\begin{array}{c}\text { Unstandardized } \\
\text { Coefficients }\end{array}$} \\
& \multicolumn{1}{c}{ B } & \multicolumn{1}{c}{ Std. } \\
& Error \\
\hline (Constant) &,- 832 &, 697 \\
MOWN & 18,544 & 11,892 \\
INST & 1,884 &, 650 \\
KI &, 249 &, 851 \\
KA &, 682 &, 622 \\
KuA &,- 208 &, 169 \\
\hline Sig. Fsize : 0,511 & \\
\hline
\end{tabular}

Berdasarkan hasil tabel uji regresi linier berganda diatas maka dapat diperoleh persamaan regresi sebagai berikut:

$\mathrm{PBV}=-0,832+18,544 \mathrm{MOWN}+1,884 \mathrm{INST}+0,249 \mathrm{KI}+0,682 \mathrm{KA}-0,208 \mathrm{KuA}+0,511 \mathrm{~F}$. size

Persamaan regresi linier berganda tersebut menunjukkan arah masing-masing variabel bebas terhadap variabel terikatnya. Nilai a adalah $-0,832$ yang menunjukkan bahwa jika kelima variabel tersebut kostan maka price to book value akan konstan sebesar -0,832.

Koefisien regresi pada variabel kepemilikan manajerial (MOWN) sebesar 18,544, artinya jika MOWN bertambah satu satuan maka variabel price to book value bertambah 18,544 dengan catatan variabel lain dianggap konstan.

Koefisien regresi pada variabel kepemilikan institusional (INST) sebesar 1,884, artinya jika INST bertambah satu satuan maka variabel price to book value bertambah 1,884 dengan catatan variabel lain dianggap konstan.

Koefisien regresi pada variabel komisaris independen (KI) sebesar 0,249, artinya jika KI bertambah satu satuan maka variabel price to book value bertambah 0,249 dengan catatan variabel lain dianggap konstan. Koefisien regresi pada variabel komite audit (KA) sebesar 0,682, artinya jika KA bertambah satu satuan maka variabel price to book value bertambah 0,682 dengan catatan variabel lain dianggap konstan.

Koefisien regresi pada variabel kualitas audit (KuA) sebesar -0,208, artinya jika KuA bertambah satu satuan maka. variabel price to book value berkurang 0,208 dengan catatan variabel lain dianggap konstan Koefisien regresi pada variabel firm size (F.size) sebesar 0,511> a $(0,05)$, artinya variabel F.size berpengaruh signifikan terhadap variabel price to book value. Sehingga F.size dapat digunakan sebagai variabel kontrol dalam penelitian.

\section{Uji kelayakan model (Uji)F}

Uji statistik F pada dasarnya menunjukkan apakah semua variabel independen atau bebas yang dimasukkan dalam model mempunyai pengaruh secara bersama-sama atau simultan terhadap variabel dependen. Uji $\mathrm{F}$ dilakukan dengan membandingkan antara nilai $\mathrm{F}_{\text {tabel }}$ dengan $\mathrm{F}_{\text {hitung }}$ hasil run regresi yang dilakukan. Hasil kelayakan model (uji F) disajikan dalam tabel sebagai berikut 
Tabel 5. Uji F

\begin{tabular}{rrr}
\hline$F_{\text {hitung }}$ & $\mathrm{F}_{\text {tabel }}$ & Sig \\
\hline 2,983 & 2,370 & 0,02 \\
\hline
\end{tabular}

Berdasarkan hasil perhitungan tersebut diperoleh nilai $F_{\text {hitung }}>F_{\text {tabel }}(2,983>2,370)$ dengan tingkat signifikan sebesar 0,02 $<0,05$ artinya hipotesis yang menyatakan bahwa secara simultan variabel independen yang terdiri dari kepemilikan manajerial, kepemilikan institusional, komisaris independen, komite audit dan kualitas audit berpengaruh signifikan terhadap nilai perusahaan.

\section{b. Uji Signifikansi Parameter Individual (Uji t)}

Menurut Ghozali (2011), uji t statistic pada dasarnya menunjukkan seberapa jauh pengaruh satu variabel independen secara individual menerangkan variabel dependen. Uji ini dilakukan dengan melihat probabilitas $t$ statistic, ketika probability $<$ taraf sig 0,05

Tabel 6.Uji T

\begin{tabular}{lccc}
\hline Variabel & t hitung & ttabel & Sig. \\
\hline MOWN & 1,559 & 2,002 & 0,124 \\
INST & 2,899 & 2,002 & 0,005 \\
KI & 0,293 & 2,002 & 0,771 \\
KA & 1,098 & 2,002 & 0,277 \\
KuA & $-1,229$ & 2,002 & 0,224 \\
\hline
\end{tabular}

Berdasarkan tabel diatas hanya kepemilikan institusional yang berpengaruh secara parsial terhadap nilai perusahaan, sedangkan variabel lain seperti kepemilikan manajerial, komisaris independen, komite audit dan kualitas audit tidak berpengaruh secara parsial terhadap niali perusahaan.

\section{c. Uji Koefisien Determinasi}

Tabel 7.Uji Koefisien Determinasi

\begin{tabular}{|l|l|l|l|}
\hline model & $\mathrm{R}$ & $\mathrm{R}^{2}$ & Adj R Square \\
\hline 1 & 0,453 & 0,205 & 0,135 \\
\hline
\end{tabular}

Berdasarkan hasil perhitungan koefisien determinasi pada tabel IV.9 dapat diketahui bahwa variabel dependen dalam hal ini price to book value dapat dijelaskan sebesar 20,5\% oleh variabel independen. Hal itu terlihat dari nilai Adjusted $R$ Square sebesar 0,205. Sedangkan sebesar 79,5\% variabel dependen price to book value dipengaruhi oleh variabel-variabel lain diluar model penelitian.

\section{Uji Korelasi Parsial}

Uji korelasi parsial disebut juga dengan analisis korelasi person menggunakan variabel kontrol atau variabel pengendali yang bernilai konstan. 
Tabel 8 Uji Korelasi Parsial

\begin{tabular}{lll}
\hline MOWN & Correlation & 0,206 \\
& Signifikansi (2-tailed) & 0,108 \\
\hline INST & Correlation & 0,338 \\
& Signifikansi (2-tailed) & 0,007 \\
\hline KI & Correlation & 0,062 \\
& Signifikansi (2-tailed) & 0,635 \\
\hline KA & Correlation & 0,165 \\
& Signifikansi (2-tailed) & 0,201 \\
\hline KuA & Correlation & $-0,133$ \\
& Signifikansi (2-tailed) & 0,304 \\
\hline
\end{tabular}

Berdasarkan nilai signifikansi diatas yang berpengaruh signifikan adalah kepemilikan institusional, karena memiliki nilai signifikansi $(0,007<0,05)$. Sedangkan untuk variabel yang lain tidak berkorelasi secara parsial.

\section{PEMBAHASAN}

\section{1) Kepemilikan Manajerial (MOWN) Tidak Berpegaruh Terhadap Nilai Perusahaan}

Hasil pengujian secara parsial menunjukkan bahwa nilai t-statistic variabel kepemilikan manajerial sebesar 1,559 yang artinya $\mathrm{t}$ hitung $<\mathrm{t}$ tabel $(1,559<2,002)$ dan tingkat probabilitas signifikansi sebesar 0,124 yang artinya signifikansi lebih besar dari $0,05(0,7395>0,05)$. Berdasarkan hasil pengujian ini dapat disimpulkan bahwa variabel kepemilikan manajerial tidak berpengaruh signifikan terhadap nilai perusahaan maka $\mathrm{H} 1$ ditolak. Hasil penelitian ini mengindikasikan bahwa kepemilikan manajerial yang tinggi akan mendorong manajemen melakukan fungsinya dengan baik, karena hal tersebut bertujuan untuk meningkatkan kepentingannya sendiri dan mengabaikan kesejahteraan pemegang saham.

Hasil penelitian ini sesuai dengan penelitian yang dilakukan oleh Dewi \& Nugrahanti (2014), Dewi \& Sanica (2017) dan Yuslirizal (2017) yang menyimpulkan bahwa kepemilikan saham manajerial berpotensi menurunkan nilai perusahaan. Namun hasil ini bertentangan dengan Syafitri, dkk (2018) dan Widyaningsih (2018) yang menyimpulkan kepemilikan manajerial berpengaruh signifikan terhadap nilai perusahaan

\section{2) Kepemilikan Institusional (INST) Berpengaruh Terhadap Nilai Perusahaan}

Hasil pengujian secara parsial menunjukkan bahwa nilai t-statistic variabel kepemilikan institusional sebesar 2,899 yang artinya $t$ hitung $>\mathrm{t}$ tabel $(2,899>2,002)$ dan tingkat probabilitas signifikansi sebesar 0,005 yang artinya signifikansi lebih kecil dari 0,05 $(0,005<0,05)$. Berdasarkan hasil pengujian ini dapat disimpulkan bahwa variabel kepemilikan institusional berpengaruh signifikan terhadap nilai perusahaan. Hasil penelitian ini mengindikasikan bahwa kepemilikan institusional yang tinggi membawa dampak pada semakin kuatnya tingkat pengendalian yang dilakukan oleh pihak institusi atas perilaku manajer yang ditujukan untuk mengurangi agensi cost sehingga manajer dapat bekerja suesuai kepentingan perusahaan untuk meningkatkan nilai perusahaan. Dengan demikian $\mathrm{H} 2$ dalam penelitian ini menyatakan kepemilikan institusional berpengaruh positif signifikan terhadap nilai perusahaan diterima.

Hasil penelitian ini sesuai dengan penelitian yang dilakukan oleh Rustan dkk (2014) dan Amrizal \& Rohmah (2017) yang menyimpulkan bahwa kepemilikan institusional berpotensi meningkatkan nilai perusahaan Namun hasil ini bertentangan dengan Dewi \& Sanica (2017) dan 
Yuslirizal (2017) yang menyimpulkan kepemilikan institusional tidak berpengaruh signifikan terhadap nilai perusahaan.

\section{3) Komisaris Independen (KI) Tidak Berpengaruh Terhadap Nilai Perusahaan}

Hasil pengujian secara parsial menunjukkan bahwa nilai t-statistic variabel kepemilikan institusional sebesar 0,293 yang artinya $t$ hitung $<\mathrm{t}$ tabel $(0,293<2,002)$ dan tingkat probabilitas signifikansi sebesar 0,771 yang artinya signifikansi lebih besar dari $0,05(0,771>0,05)$. Berdasarkan hasil pengujian ini dapat disimpulkan bahwa variabel komisaris independen tidak berpengaruh signifikan terhadap nilai perusahaan. Hasil penelitian ini mengindikasikan bahwa proporsi komisari independen yang tinggi tidak berpengaruh pada nilai perusahaan. Hal tersebut disebabkan oleh ratarata komposisi dewan komisaris independen saat ini kurang efisien dalam menjalankan fungsi pengawasan karena proporsi komisaris independen belum mampu untuk mendominasi setiap kebijakan yang diambil oleh dewan komisaris. Kurang efektifnya pengawasan pelaporan keuangan misalnya dapat menyebabkan kecurangan pelaporan keuangan oleh pihak manajemen sehingga menyebabkan harga saham menurun dan nilai perusahaan semakin menurun. Selain itu minimnya pemantauan terhadap pihak manajemen yang dilakukan oleh dewan komisaris dan akuntabilitas dewan komisaris terhadap perusahaan dan pemegang saham akan menimbulkan konflik agensi yang akhirnya akan berdampak pada menurunnya nilai perusahaan. Dengan demikian H3 dalam penelitian ini menyatakan komisaris independen berpengaruh positif signifikan terhadap nilai perusahaan ditolak.

Hasil penelitian ini sesuai dengan penelitian yang dilakukan oleh Firdausya dkk (2013), Widyaningsih (2018) yang menyimpulkan bahwa komisaris independen tidak berpengaruh terhadap nilai perusahaan. Namun hasil ini bertentangan dengan Dewi \& Nugrahanti (2014), Raharja (2014). yang menyimpulkan komisaris independen berpengaruh signifikan terhadap nilai perusahaan.

\section{4) Komite Audit (KA) Tidak Berpengruh Terhadap Nilai Perusahaan}

Hasil pengujian secara parsial menunjukkan bahwa nilai t-statistic variabel komite audit sebesar 1,098 yang artinya $t$ hitung $<\mathrm{t}$ tabel $(1,098<2,002)$ dan tingkat probabilitas signifikansi sebesar 0,771 yang artinya signifikansi lebih besar dari $0,05(0,277>0,05)$. Berdasarkan hasil pengujian ini dapat disimpulkan bahwa variabel komite audit tidak berpengaruh signifikan terhadap nilai perusahaan komite audit bukanlah menjadi salah satu faktor penentu untuk meningkatkan efektifitas fungsi komite audit, khususnya yang berhubungan dengan benturan kepentingan, perbuatan yang merugikan perusahaan, dan kecurangan (FCGI, 2008). Dengan demikian H4 dalam penelitian ini yang menyatakan komite audit berpengaruh terhadap nilai perusahaan ditolak.

Hasil penelitian ini sesuai dengan penelitian yang dilakukan oleh Amrizal A dkk (2017), Syafitri dkk (2018) yang menyimpulkan bahwa komite auditt tidak berpengaruh terhadap nilai perusahaan. Namun hasil ini bertentangan dengan Widyasari, dkk (2015) dan Widyaningsih (2018) yang menyimpulkan komite audit berpengaruh terhadap nilai perusahaan.

\section{5) Kualitas Audit (KuA) Tidak Berpengaruh Terhadap Nilai Perusahaan}

Hasil pengujian secara parsial menunjukkan bahwa nilai t-statistic variabel kualitas audit sebesar $-1,229$ yang artinya $\mathrm{t}$ hitung $<\mathrm{t}$ tabel $(-1,229<2,002)$ dan tingkat probabilitas signifikansi sebesar 0,771 yang artinya signifikansi lebih besar dari $0,05(0,277>0,05)$. Berdasarkan hasil pengujian ini dapat disimpulkan bahwa variabel kualitas audit tidak berpengaruh signifikan terhadap nilai perusahaan. Dengan demikian H5 dalam penelitian ini yang menyatakan kualitas audit tidak berpengaruh terhadap nilai perusahaan diterima. 
Hasil penelitian ini sesuai dengan penelitian yang dilakukan oleh Widyasari, dkk (2015) dan Amrizal \& Rohmah (2017) yang menyimpulkan bahwa kualitas audit tidak berpengaruh terhadap nilai perusahaan. Namun hasil ini bertentangan dengan Raharja (2014) yang menyimpulkan kualitas audit berpengaruh terhadap nilai perusahaan.

6) Variabel Independen (MOWN, INST, KI, dan KA) Terhadap Nilai Perusahaan Dengan Firm Size Sebagai Variabel Kontrol

Variabel kontrol adalah variabel yang dikendalikan atau dibuat konstan sehingga pengaruh variabel independen terhadap dependen tidak dipengaruhi oleh faktor luar yang tidak diteliti (Sugiyono, 2009). Variabel kontrol ini untuk mengetahui apakah variabel firm size perlu dinetralisir, dikeluarkan, atau dipertahankan tetap. Pada penelitian ini menggunakan aplikasi studi korelasional yaitu korelasi parsial. Berikut hasil uji hipotesis variabel independen (MOWN, INST, KI, KA, dan $\mathrm{KuA}$ ) terhadap nilai perusahaan (PBV) dengan firm size sebagai variabel kontrol. Berdasarkan uji korelasi Tabel IV.10, dapat dilihat bahwa nilai signifikan dari keempat variabel (kepemilikan manajerial, komisaris independen, komite audit, serta kualitas audit) > 0,05 yang berarti terdapat korelasi yang tidak signifikan antara kepemilikan manajerial, komisaris independen, komite audit, serta kualitas audit dengan nilai perusahaan. Namun demikian untuk kepemiikan institusional memiliki nilai signifikansi $<0,05(0,07<0,05)$, yang berarti terdapat korelasi yang signifikan antara kepemilikan institusional dengan nilai perusahaan. Dengan demikian H6 dalam penelitian ini yang menyatakan firm size berpengaruh terhadap nilai perusahaan dan mampu mengendalikan pengaruh variabel kepemilikan manajerial, kepemilikan institusional, komisaris independen, komite audit dan kualitas audit terhadap nilai perusahaan ditolak. Hasil penelitian ini bertentangan dengan penelitian yang dilakukan oleh Widyaningsih (2018) yang menyimpulkan firm size sebagai variabel kontrol berpengaruh signifikan terhadap nilai perusahaan.

\section{KESIMPULAN}

Secara simultan kepemilikan manajerial, kepemilikan institusional, komisaris independen, komite audit, serta kualitas audit berpengaruh terhadap nilai perusahaan. Namun secara parsial, kepemilikan institusional yang berpengaruh positif signifikan terhadap nilai perusahaan, sedangkan variabel bebas lainnya (kepemilikan manajerial komisaris independen, komite audit dan kualitas audit) berpengaruh positif tetapi tidak signifikan terhadap nilai perusahaan

\section{DAFTAR PUSTAKA}

Timbuleng, S., \& Sumarauw, J. S. (2015). Etos Kerja, Disiplin Kerja, Dan Komitmen Organisasi Pengaruhnya Terhadap Kinerja Karyawan Pada Pt Hasjrat Abadi Cabang Manado. Jurnal EMBA: Jurnal Riset Ekonomi, Manajemen, Bisnis dan Akuntansi, 3(2).

Nurlela, I. (2008). Pengaruh Corporate Social Responsibility Terhadap Nilai Perusahaan Dengan Prosentase Kepemilikan Manajemen Sebagai Variabel Moderating. Simposium Nasional Akuntansi $X I$.

Sholekah, Febrina W dan Venusita. 2014. "Pengaruh Kepemilikan Manajerial, Kepemilikan Institusional, Leverage, Firm Size dan Corporate Social Responsibility Terhadap Nilai Perusahaan Pada Perusahaan High Profile yang Terdaftar Di Bursa Efek Indonesia Periode Tahun 2008-2012." Jurnal Ilmu Manajemen. Volume 2 Nomor 3. 
Purwantini, V. T. (2011). Pengaruh Mekanisme good Corporate Governance Terhadap Nilai Perusahaan dan Kinerja Keuangan Perusahaan (Studi pada Perusahaan-Perusahaan Manufaktur yang Terdaftar di Bursa Efek Indonesia). Jurnal dipublikasikan. STIE AUB Surakarta.

Marius, M. E., \& Masri, I. (2017). Pengaruh Good Corporate Governance Dan Corporate Social Responsibility Terhadap Nilai Perusahaan. Konferensi Ilmiah Akuntansi IV, 1(2), 1-22.

Dewi, L. C., \& Nugrahanti, Y. W. (2017). Pengaruh Struktur Kepemilikan dan Dewan Komisaris Independen terhadap Nilai Perusahaan (Studi pada Perusahaan Industri Barang Konsumsi di Bei Tahun 2011â€"2013).

Yuslirizal, A. (2017). Pengaruh Kepemilikan Manajerial, Kepemilikan Institusional, Growth, Likuiditas dan Size terhadap Nilai Perusahaan pada Industri Tekstil dan Garmen di Bursa Efek Indonesia. Katalogis, 5(3).

Dewi, K. R. C., \& Sanica, I. G. (2017). Pengaruh Kepemilikan Institusional, Kepemilikan Manajerial, dan Pengungkapan Corporate Social Responsibility terhadap Nilai Perusahaan Pada Perusahaan Manufaktur yang Terdaftar di Bursa Efek Indonesia. Jurnal Ilmiah Akuntansi dan Bisnis, 2(1), 231246. 